Boletín de la Sociedad Geológica Mexicana

VOLUMEN 64, NÚM. 2, 2012, P. 171-176

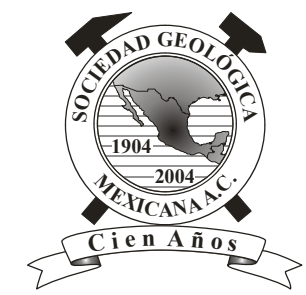

\title{
The study of biogenic silica in animal dung deposits from the Moscow Kremlin, Russia
}

\author{
Alexandra A. Golyeva ${ }^{1, *}$ \\ ${ }^{1}$ Institute of Geography, Russian Academy of Sciences, Moscow, Russia, 119017. \\ *alexandragolyeva@rambler.ru
}

\begin{abstract}
Several ancient settlements from Central Russia contain animal dung deposits as a part of their cultural layers. This research was focused on animal dung of different ages sampled in the archeological dig in Taynitsky Garden, Moscow Kremlin, Russia. The method of research was microbiomorphic analysis. The distribution of silica microbiomorphs and the composition of phytolith complexes were analyzed as the most informative. It is possible to see that indicators of open waters (diatoms and spicules) were identified only in one sample (the earliest one dated to the beginning of the $15^{\text {th }}$ century). Phytolith complexes also changed: the samples from layers dated to the late $15^{\text {th }}$ and the early $16^{\text {th }}$ centuries include a lot of cereal straw phytoliths. This fact definitely indicates changes in the animals' diet. Phytoliths from mosses and reeds show that those plants were used as animal bedding. An abundance of fragments and unformed silica particles suggests that grasses and herbs were mowed in summer, when the phytolith formation process had not yet completed. It is possible to say that at the end of the $15^{\text {th }}$ century animals consumed water from wells, suggesting that the construction of the Kremlin wall was finished and the area became isolated from the bank of the Moscow River. Also, the animals' diet changed - straw became dominant instead of hay, possibly linked to a political and economical situation in the country. Conclusions are in reasonable agreement with archeological and historical data.
\end{abstract}

Keywords: Moscow Kremlin, dung, phytoliths, diatoms, reconstructions.

\section{Resumen}

Diversos asentamientos antiguos de Rusia Central contienen depósitos de excremento de animales como parte de sus capas culturales. Esta investigación se enfoca al estiércol animal de diferentes edades, muestreado en una excavación arqueológica en el jardín Tanytsky, dentro del Kremlin de Moscú, Rusia. El método de la investigación fue el análisis microbiomórfico. La distribución de microbiomorfos de sílice y la composición de los complejos de fitolitos fueron analizadas como las más informativas. Es posible observar que los indicadores de aguas abiertas (diatomeas y espículas) fueron identificados únicamente en una muestra (la más joven perteneciente al inicio del siglo 15). Los complejos de fitolitos también cambiaron: las muestras de las capas que corresponden a finales del siglo 15 e inicios del 16 incluyen una gran cantidad de fitolitos de paja de cereal. Este hecho definitivamente indica cambios en la dieta de los animales. Los fitolitos de musgos y carrizos muestran que estas plantas fueron usadas como paja para el ganado. La abundancia de fragmentos y partículas de sílice amorfas sugiere que los pastos y hierbas eran podados en el verano, cuando el proceso de formación de fitolitos no se había completado todavía. Es posible decir que a finales del siglo 15, los animales tomaban agua de pozos, lo que significa que la construcción del muro del Kremlin fue terminado y que el área quedó aislada del banco del río Moscú. También cambió la dieta de los animales - la paja se volvió dominante en lugar del heno, posiblemente en relación con la situación politica y económica de la región. Las conclusiones son acordes con los datos arqueológicos e históricos.

Palabras clave: Kremlin de Moscú, estiércol, fitolitos, diatomeas, reconstrucción. 


\section{Introduction}

When excavating medieval settlements of ancient Russia, dung deposits of various thicknesses and degrees of preservation are often found. These layers are usually described (Khoroshev, 1998; Sycheva et al., 2000) as a part of the sequence, but unlike other types of cultural layers, they are not otherwise investigated in any way. As a result, the present-day situation in Russia is such that specialists in natural sciences have studied in great detail even the thinnest interlayers and laminas within cultural layers of the settlements, while thicker layers (occasionally several meters thick) are neglected. There are no Russian papers in which the dung deposits are considered either as a constituent of the cultural layers of a particular settlement or as an independent source of information (Sergina, 2004; Passek, 2006; Lapshin, 2009). Contrary to this, the international scientific literature provides many examples of those deposits studied thoroughly and meticulously and producing interesting results. (Bryant, 1974; Rheinhard and Bryant, 1992; Carrión, 2002; Karkanas et al., 2002; Horrocks et al., 2003; Prasad et al., 2005; Bird et al., 2007; Bryant and Dean, 2006; Ghosh et al., 2008; Sánchez et al., 2010; Lewis, 2011; Shahack-Gross, 2011).

In the light of all the above, the goal of the work may be stated as follows: to estimate the potentialities of dung deposits within medieval cultural layers of Moscow as information resources.

A series of chemical and microbiomorphic analyses were performed in order to reveal general and specific characteristics of every sample taken.

\section{Materials and methods}

In 2007 protective excavations were undertaken in the Taynitsky Garden area of the Moscow Kremlin territory (Figure 1) under the guidance of the archaeologists V.Yu, Koval, T.D. Panova, and D.O. Osipov. In the course of digging, dung deposits of different age were exposed and described in unit A5, excavation II, and sampled for laboratory analysis. Altogether five samples were taken from archeologically dated dung layers (from the bottom upwards) as follows: beginning, middle and end of the $15^{\text {th }}$ century (approximately 1470); and beginning and middle of the $16^{\text {th }}$ century.

\subsection{Morphological characteristics of the studied profile}

As seen clearly in Figure 1, the exposure demonstrates heterogeneous, loose laminated sediments having a predominantly grey colour. Archeologists assume that the whole deposit consists mainly of dung, whereas lamination is caused by the admixtures typical of dung sediments. The lowest two samples (beginning and middle of the $15^{\text {th }}$ century) are taken from a darker homogeneous material

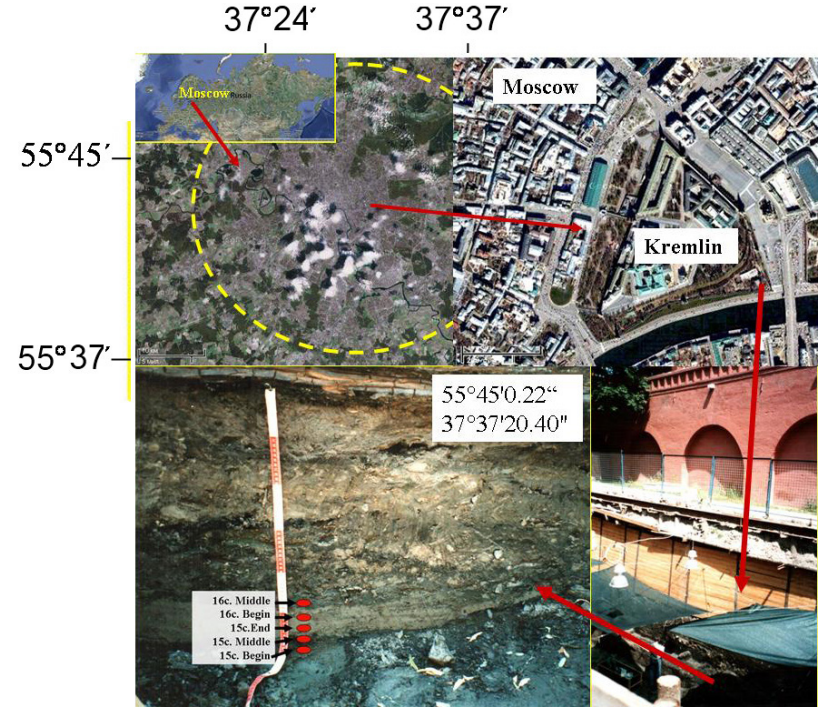

Figure 1. Study site location inside the Moscow Kremlin; red dots in the profile indicate the place of sampling.

without coarse organic or mineral inclusions. The material does not react with $\mathrm{HCl}$.

The samples corresponding to the strata dated to the end of the $15^{\text {th }}$ and beginning of the $16^{\text {th }}$ centuries originate from a somewhat compacted light-grey layer with a number of yellowish-white inclusions. An intensive reaction with $\mathrm{HCl}$ points to the presence of carbonates.

The material of the uppermost sample (middle of $16^{\text {th }}$ century) contains abundant wood fragments that are characterized by a lighter colour and less compaction compared to the underlying strata. Presence of fine carbonate particles is the reason for a strong reaction with $\mathrm{HCl}$.

Standard chemical analyses for archeological soil studies were carried out. Chemical properties of samples were determined using conventional procedures (Arinushkina, 1970; Vorobiova, 1998, 2006).

$\mathrm{pH}$ was determined by potentiometry in a soil:water (or 1 $\mathrm{M} \mathrm{KCl}$ ) suspension with a ratio of $1: 2.5$ and single shaking followed by settling for 30 minutes $\left(\mathrm{pH}_{\mathrm{H} 2 \mathrm{O}}\right)$ or 18 to 20 hours with periodical mixing $\left(\mathrm{pH}_{\mathrm{KCl}}\right)$ (Arinushkina, 1970).

Organic carbon was determined by the Tyurin method, which included the wet digestion of organic substance in a mixture of $0.4 \mathrm{~N} \mathrm{~K}_{2} \mathrm{Cr}_{2} \mathrm{O}_{7}$ and concentrated $\mathrm{H}_{2} \mathrm{SO}_{4}(1: 1)$ heated to $150{ }^{\circ} \mathrm{C}$ for 20 minutes. Later on, measurements were performed by photometry on a SPECOL 211 spectrometer at $590 \mathrm{~nm}$ (Arinushkina, 1970).

Carbonates in the sample were determined by alkalimetry using the Kozlovskii procedure. A soil sample was treated with $2 \mathrm{M} \mathrm{HCl}$; the released $\mathrm{CO}_{2}$ was absorbed by a $0.4 \mathrm{M}$ $\mathrm{NaOH}$ solution. Then, a saturated $\mathrm{BaCl}_{2}$ solution was added to the tube with $\mathrm{NaOH}$, and the excess of alkali was titrated with $0.2 \mathrm{M} \mathrm{HCl}$ (Vorobiova, 1998, 2006).

Total phosphorus. The procedure includes a sample burned with concentrated sulfuric acid on the heater. Phosphate in the extract is evaluated colorimetrically using 
a spectrophotometer SPECOL 211 with the blue ammonium molybdate method and ascorbic acid as the reducing agent (Vorobiova, 1998, 2006).

The main method was phytolith analysis using the standard procedure (Piperno, 1988, 2006; Sudbury, 2011a). After treatment with hot $30 \%$ solution of $\mathrm{H}_{2} \mathrm{O}_{2}$, samples (about $50 \mathrm{~g}$ ) were separated from sands and clay and subjected to flotation in heavy liquid (cadmium iodide and potassium iodide solution with a gravity of about 2.3). After centrifugation, the floating phytoliths and other biomorphs were collected in a tube, washed several times with distilled water and studied under the optical microscope. Quantitative and qualitative analyses were made according Golyeva (2007) and Sudbury (2011a).

Biomorph studies were employed using a multidisciplinary approach and including a number of specific microscopic analyses. The biomorphic analysis is the microscopic investigation of plant tissue, detritus, phytoliths, pollen and other macro and micro remains of biota for the reconstruction of ancient pedogenic conditions. Each of the biomorph types is intimately associated with certain types of landscapes and provides information about soil development conditions and landscape evolution. In every particular case, one of the analyses appears to be most informative, all the rest providing additional and corrective information or an independent control of the results obtained. Every type of deposit forms its own biomorph assemblages. Deposits of different stages can be studied separately (Golyeva, 2001, 2008).

The analyses were performed in the Chemical Laboratory of the Institute of Geography (Russian Academy of Sciences) by analysts A.M. Chugunova, E.A. Agafonova, and I.V. Turova. Microbiomorphs were studied in four samples only; the sample dated to the mid- $15^{\text {th }}$ century was not analyzed for technical reasons.

\section{Results and discussion}

\subsection{Data of chemical analyses}

Results of chemical analyses are shown in Figure 2. The acidity is neutral throughout the sequence ( $\mathrm{pH} 7)$, although other characteristics (total phosphorus content and that of carbon fixed in carbonates) vary over a wide range. It may be safely stated that the entire series presents a well-balanced neutral medium, which accounts for excellent agrochemical properties of decomposed dung.

Organic carbon is present in abundance, which is typical both of cultural layers and of organic deposits such as dung. The proportion of organic constituents decreases towards the middle of the $16^{\text {th }}$ century; that may be attributed to a considerable admixture of practically undecomposed sawdust in the dung layer, as well as to presence of construction debris mixed with the dung.

Total phosphorus is found in all the samples in quantities

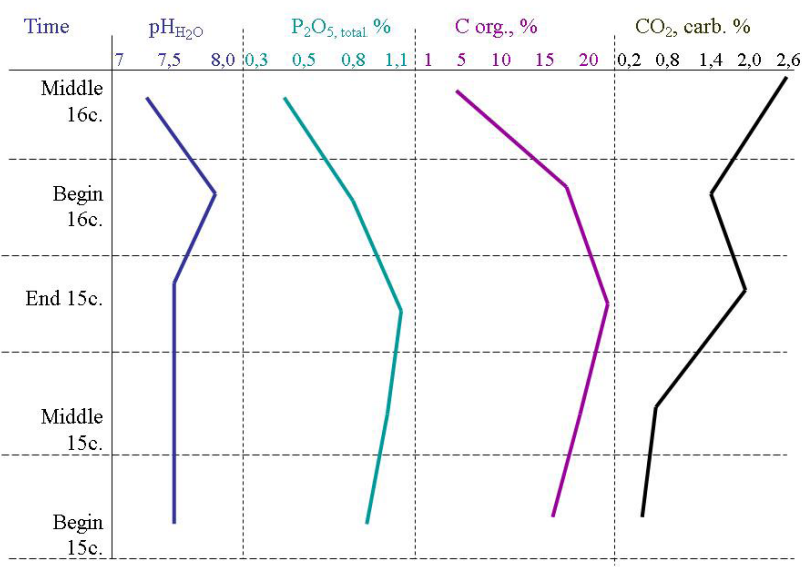

Figure 2. Selected chemical analyses of the samples.

exceeding standard; that suggests the whole sequence formed as a result of human activities. It is noteworthy that, even in the oldest of the studied layers (dated to the beginning of the $15^{\text {th }}$ century), phosphorus content is four times greater than in natural soils; consequently, the layer was not the first in the formation history of the cultural layers. Maximum values of phosphorus content are recorded in the layer dated to the late $15^{\text {th }}$ century. Most likely, it was a result of fires, when organic layers subjected to compaction and absolute accumulation of many biogenic elements took place. That conjecture is supported by the maximum of organic matter content in the same layer. Minimum values of phosphorus are found in the layer dated to the middle of $16^{\text {th }}$ century, and the data are in reasonable agreement with lowered values of organic carbon. That may be attributed to the same factor, namely a sizeable admixture of phosphorusdeficient construction waste and sawdust. It should be noted, however, that even those lower values are $1.5-2$ times higher than those in natural soils; therefore, the upper layer, in common with all the others, is a product of human activities and not of natural factors.

Content and distribution of carbon fixed in carbonates is also interesting and informative. Two blocks are distinctly recognized in the studied series: the first, including the beginning and middle of the $15^{\text {th }}$ century, is practically devoid of carbonates, while the second block, spanning the end of the $15^{\text {th }}$ to the middle of the $16^{\text {th }}$ centuries, abounds in them. As the older layers occur lower in the sequence, it is quite possible that initially the carbonate content was even less than at present, and that today's values resulted from diagenetic carbonates being gradually illuviated with rainwater. The suggestion is substantiated with the somewhat higher carbonate content in the layer dated to the middle of the $15^{\text {th }}$ century as compared with underlying ones. The sharp increase recorded in carbonates is directly related to the beginning of stone house-building. The limestone used in construction enriched the cultural layers with carbonates. The same construction material-limestone - was commonly in use at this place ever since. 


\subsection{Biomorphic studies}

All the samples contained a great quantity of various detritus, cuticle casts of grass and amorphous organic matter, as is typical of cultural layers.

The most valuable sources of information turned out to be the content and distribution of siliceous biomorphs (phytoliths, diatom testae, sponge spicules), as well as the dynamics of the phytolith assemblage composition. Below are considered all of the analyses in greater detail.

The amount and distribution of biogenic silica is shown in Figure 3. It is clear that only one sample contains diatom algae and sponge spicules -that is the oldest of the studied layers, dated to the early $15^{\text {th }}$ century. Both diatoms and sponge spicules are indicative of open water bodies (Battarbee, 1986; Sudbury, 2011b; Winsborough, 2011). Their presence in the dung samples is logical, as animals need water. Much more interesting is the fact that diatoms and spicules are absent from later samples. As all the samples are animal dung and the animals had to be given water regularly, the lack of open water indicators suggests the water was obtained from closed (isolated) sources. Diatoms and sponges could not survive in such conditions because of insufficient light and organic matter supply. One of explanations for the changes in water sources could be construction of a defensive wall at the studied site which barred direct access to river water.

As is typical of dung layers, phytoliths are abundant in the samples. The only exception is the latest layer dated to the middle of the $16^{\text {th }}$ century, where phytoliths are less than half as abundant as in other samples. That may be attributed to a considerable proportion of wood debris (sawdust and wood shavings) in the layer; the proportion of phytoliths being accordingly reduced.

Distribution of various groups of phytoliths also provided interesting data (Figure 3). Phytoliths of mosses, ferns and coniferous plants are present in all the samples; that is likely attributable to the composition of animal bedding. This is also true for reed phytoliths. That is to say, the layers described as animal dung in the field consist actually both of dung and of decomposed animal bedding. Besides, the high proportion of coniferous phytoliths in the sample dated to the mid- $16^{\text {th }}$ century $(21 \%$ of the total number of phytoliths) is definitely related to a noticeable presence of wood remains (including those of coniferous trees) in the layer.

The diversity of phytolith assemblages (Figure 4) suggests that the grass for hay was cut in different environments, including forest, meadow, dry hill-sides, and probably sedge wetlands.

The proportion of cultivated grass (Gramineae) phytoliths amounts to $6 \%$ in the earliest sample (beginning of the $15^{\text {th }}$ century), increases sharply to $25 \%$ at the end of the $15^{\text {th }}$ century, and decreases again by the beginning of the $16^{\text {th }}$ century. In cultivated grasses phytoliths develop in stems, leaves and grain husks. In the studied assemblages,

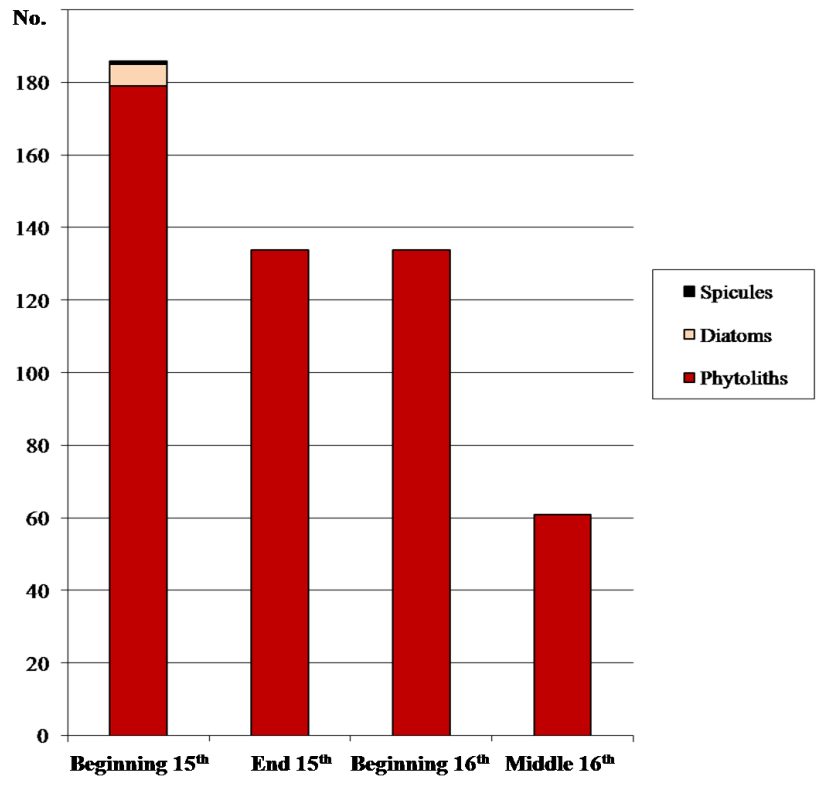

Figure 3. Silica biomorph distribution.

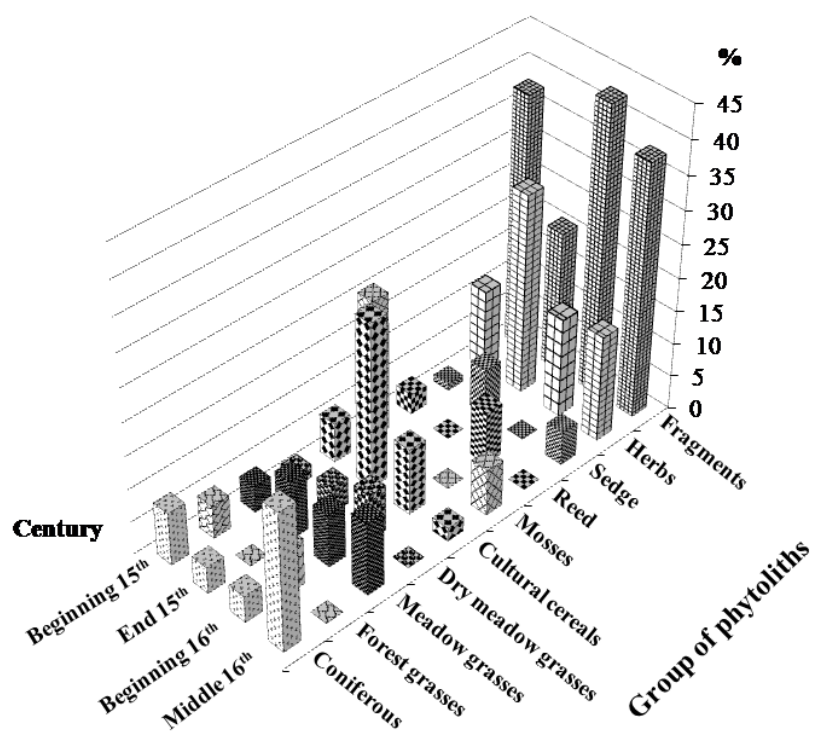

Figure 4. Different forms of phytoliths found in the samples.

there are only phytoliths of stems and leaves, that is, of straw. Such dynamics in the Gramineae phytoliths indicates some changes in the animal diet-from hay in early $15^{\text {th }}$ century to mostly straw by the end of the century; later the proportion of hay in the animal feed gradually rises. The reason for such dynamics is still unclear; it is not inconceivable that it may be related to changes in the economic situation.

A relatively high proportion of underdeveloped phytoliths is typical of dung, as grass for haymaking is cut in the middle of summer when the process of phytolith development in plant cells is not completed. 


\section{Conclusions}

1. Dung layers included in the series of cultural layers are complex from the standpoint of information. On one hand, they are animal waste products and therefore provide data on the animals' diet. On the other, as a part of the total cultural layer in the excavated settlement, they acquire certain characteristics that may provide information on the environments at the time of the layer deposition: pine forests and arable lands on watershed and terraces, meadow and reeds near the river.

2. The studied deposits represent a chemically balanced organic mass; besides the dung itself, they include livestock bedding and domestic waste (in the $15^{\text {th }}$ century in particular), and later (the $16^{\text {th }}$ century) construction waste as well. Variations in total phosphorus content clearly indicate the increase of domestic activities throughout the $15^{\text {th }}$ century and the onset of active usage of stone (limestone) in construction since the end of the $15^{\text {th }}$ century (the latter was inferred from dynamics of inorganic carbon fixed in carbonates). Stages of construction using wood and stone are clearly distinguishable; it may be safely suggested that limestone came into use instead of timber about 1470 .

3 . The high content of total phosphorus in the earliest samples studied indicates that the area was inhabited long before the beginning of the $15^{\text {th }}$ century (age of the lowest sample), and the studied deposits lie over older cultural layers.

4. Content and distribution of chemical elements and biomorphs provide adequate information on stages of domestic activities and construction: it has been shown, for example, that in the early $15^{\text {th }}$ century drinking water for animals was taken from the river, while later from a well as the river became inaccessible.

5. The analysis of phytolith distributions in dung layers of different age reveals changes in animal diet with time and provides evidence for cattle management practices at certain time intervals: for example, the predominance of straw in the animals' diet typical of the end of the $15^{\text {th }}$ and beginning of the $16^{\text {th }}$ centuries (unlike the previous and subsequent periods) may be attributed to some economic problems.

6. It may be seen, therefore, that dung deposits contain a substantial volume of information and represent a more complicated and ambiguous object for study as compared with typical ("classic") cultural layers.

\section{References}

Arinushkina, E.V., 1970, Guide on the Chemical Analysis of Soils: Moscow, Moscow State University Publishing House, 487 p. (in Russian)

Battarbee, R.W., 1986, Diatom analysis, in Berglund, B.E. (ed), Handbook of Holocene Palaeoecology and Palaeohydrology: Chichester, U.K., Wiley, 527-570.

Bird, M.I., Boobyer, E.M., Bryant, C., Lewis, H.A., Paz, V., Stephens, W.E., 2007, A long record of environmental change from bat guano deposits in Makangit Cave, Palawan, Philippines: Earth and Environmental Science Transactions of the Royal Society of Edinburgh, 98, 59-69.

Bryant, V.M., 1974, Pollen analysis of prehistoric human feces from Mammoth Cave, Kentucky, in Watson, P.J. (ed.), Archaeology of the Mammoth Cave Area: New York, Academic Press, 203-209.

Bryant, V.M., Dean, G.W., 2006, Archaeological coprolite science: The legacy of Eric O. Callen (1912-1970): Palaeogeography, Palaeoclimatology, Palaeoecology, 237, 51-66.

Carrión, J.S., 2002, A taphonomic study of modern pollen assemblages from dung and surface sediments in arid environments of Spain: Review of Palaeobotany and Palynology, 120, 217-232.

Ghosh, R., Gupta, S., Bera, S., Jiang, H., Li, X., Li, C.S., 2008, Ovicaprid dung as an indicator of paleovegetation and paleoclimate in northwestern China: Quaternary Research, 70, 149-157.

Golyeva, A., 2001, Biomorphic analysis as a part of soil morphological investigations: Catena, 43, 217-230.

Golyeva, A., 2007, Various phytolith types as bearers of different kinds of ecological information, in Madella M., Zurro D. (eds.), Plants, People and Places. Recent Studies in Phytolith Analysis: Oakville, Connecticut, Oxbow Books, 196-201.

Golyeva, A., 2008, Microbiomorphic Analysis as a Tool for Natural and Anthropogenic Landscape Investigations: Genesis, Geography, Interpretation: Moscow, URSS Press, 240p. (in Russian).

Horrocks, M., Irwin, G.J., McGlone, M.S., Nichol, S.L., Williams, L.J., 2003, Pollen, Phytoliths and diatoms in prehistoric coprolites from Kohika, Bay of Plenty, New Zealand: Journal of Archaeological Science, 30, 13-20.

Karkanas, P., Riguad. J.Ph., Simek, J.F., Albert, R.M., Weiner, S., 2002, Ash bones and guano: a study of the minerals and phytoliths in the sediments of Grotte XVI, Dordogne, France: Journal of Archaeological Science, 29, 721-732.

Khoroshev, A.S., 1998, Cultural layer of Novgorod as an ecological structure: Culture and Nature of the Ancient Town, 83-84 (in Russian).

Lapshin, V.A., 2009, Tver in $13^{\text {th }}-15^{\text {th }}$ century (on results of excavation on the Tver kremlin-11, 1993-1997): St. Petersburg, Publishing House of the Philological Faculty of St. Petersburg University, 342 p. (in Russian).

Lewis, M.D., 2011, Pleistocene Hyaena coprolite palynology in Britain: Implications for the environments of early humans: Developments in Quaternary Science, 14, 263-278.

Passek, T.S., 2006, Cultural layers of ancient Moscow (on-line document): available at < www.rusarch.ru/passek1.htm>, retrieved 15 May 2012.

Piperno, D.R., 1988, Phytolith Analysis: an Archaeological and Geological Perspective: San Diego, California, Academic Press, 280 p.

Piperno, D.R., 2006, Phytoliths: A Comprehensive Guide for Archaeologists and Paleoecologists: Lanham, Maryland, AltaMira Press, 238 p.

Prasad, V., Strömberg, C.A.E., Alimohammadian, H., Sahni, A., 2005, Dinosaur coprolites and the early evolution of grasses and grazers: Science, 310, 1177-1180.

Rheinhard, K.J. and Bryant, V.M., 1992, Coprolite analysis: a biological perspective on archaeology, in Schiffer, M.B. (ed.), Archaeological Method and Theory: Tucson, Arizona, University of Arizona Press, 245-288.

Sánchez, M.V., González, M.G., Genise, J.F., 2010, Phytolith analysis of Coprinisphaera, unlocking dung beetle behavior, herbivore diets and palaeoenvironments along the Middle Eocene-Early Miocene of Patagonia: Palaeogeography, Palaeoclimatology, Palaeoecology, 285, 224-236.

Sergina, T.V., 2004, The project of protection zones of the cultural layer of Vyazma and problems of conservation of the archaeological heritage of the Smolensk region: Archaeology and History of Pskov and Pskov Lands, 396-409 (in Russian).

Shahack-Gross, R., 2011, Herbivorous livestock dung: formation, taphonomy, methods for identification, and archaeological significance: Journal of Archaeological Science, 38, 205-218.

Sudbury, J.B., 2011a, Quantitative Phytolith Analysis - A Working Example from Modern Prairie Soils and Buried Holocene A Horizons: Ponca City, Oklahoma, Phytolith Press, 288 p. 
Sudbury, J.B., 2011b, Sponge spicules in the Opossum Creek soil profile, Nowata County, Northeastern Oklahoma, in Sudbury, J.B. (ed.), Biogenic Silica from an Opossum Creek soil profile, Nowata County, Oklahoma USA: Ponca City, Oklahoma, Phytolith Press, 75-103.

Sycheva, S.A., Leonova, N.B., Usianov, A.A., Alexandrovskii, A.L., Pustovoitov, K.Eu., 2000, The evolution of the cultural layers of the Holocene age: Izvestia of the Russian Academy of Sciences, Geography Series, 4, 29-37 (in Russian).

Vorobiova, L.A., 1998, Chemical Analysis of Soils: Moscow, Moscow State University Publishing House, 272 p. (in Russian).

Vorobiova, L.A., 2006, Theory and Practice of the Chemical Analysis of Soils: Moscow, Geos, 400 p. (in Russian).
Winsborough, B.M., 2011, Paleoenvironmental analysis of the Opossum Creek diatom assemblage, in Sudbury, J.B. (ed.), Biogenic Silica from an Opossum Creek Soil Profile, Nowata County, Oklahoma USA: Ponca City, Oklahoma, Phytolith Press, 43-75.

Manuscript received: November 15, 2010

Corrected manuscript received: June 10, 2011.

Manuscript accepted: January 10, 2012. 